هجلة طلية الآثايب. باهعة الإسكندرية ـ المجلد 79 ـ العقد 91 .

\title{
Rhetorical Strategies Used in the Military Statements on the Comprehensive Operation Sinai 2018
}

\author{
By: Prof. Miranda Mohamed Khamis El-Zouka \\ Professor of Linguistics
}

English Department- Faculty of Arts

Damanhour University 


\section{$\underline{\text { Abstract }}$}

After the initiation of the Comprehensive Operation Sinai 2018, the Egyptian armed forces started to issue military statements to update Egyptians with the latest achievements that have been made in fighting terror groups. The study aims at investigating the rhetorical strategies used in the military statements issued by the Egyptian armed forces concerning the Comprehensive Operation Sinai 2018. It also investigates the linguistic devices and lexical items used in these strategies. The study applies the rhetorical strategies proposed by Nugus (2009) as well as other strategies that the researcher has found in the data, which are "assuming power and authority" and "glorification". In this way, a comprehensive of the rhetorical strategies that can be used in the analysis of military statements is achieved. It also presents a quantitative analysis of each of these strategies. The study reveals that the most commonly used strategy is "Objectifying" and the least used one is "identifying".

Key Words: Military Statements, terror, Sinai, rhetorical strategies

الاستراتيجبات الخطابية المستخدمة في البيانات العسكرية الخاصة بالعملية الثاملة سيناء

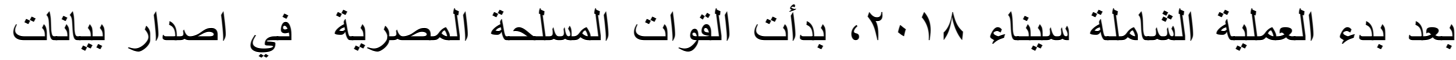

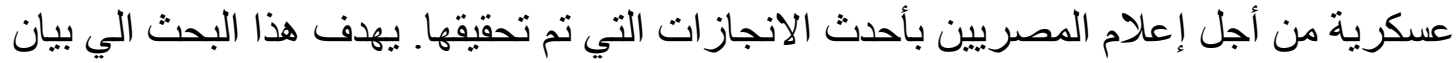
الاستر اتيجيات الخطابية المستخدمة في البيانات العلات العسكرية الخاصة بالعملية الشاملة سيناء

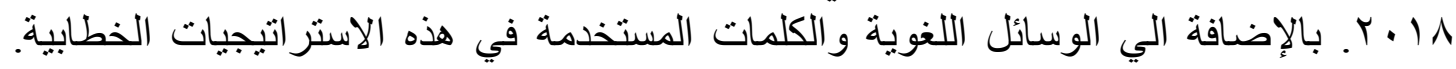
ويستخدم البحث الاستراتيجيات التي اقترحها نوجوس (2009) بالإضافة الي استراتيجيتين

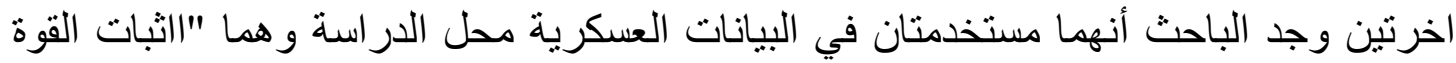

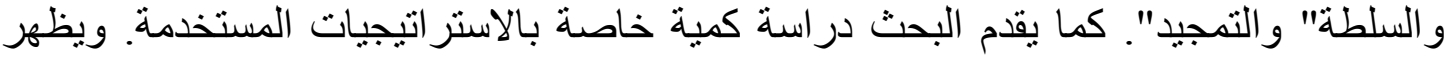
البحث أن أكثر الاستر اتيجيات استخداما هي "الحيادية" و أقلها استخداما هي "تحديد الهوية" 


\section{1-Introduction}

Language reflects the society and the culture in which it is used. Military has its own culture and beliefs. Thus, military discourse has its own distinctive linguistic features, which are a reflection of the difficult conditions of military life. It is necessary to understand the "social and contextual background of military life in order to effectively appreciate how the functionality of language used in the military demands particular linguistic terms" (Okongor, 2015, p. 653).

\section{2-Aims of the Study}

Military discourse is an important means of communication. The main function of the military in all countries of the world is to maintain the safety and the stability of the state. Thus, military discourse provides support for the main aims of the armed forces.

After the initiation of the Comprehensive Operation Sinai 2018, the Egyptian Minister of Defense started to issue official military statements to update Egyptians on the latest achievements of the Egyptian armed forces in Sinai.

This study aims at investigating the rhetorical strategies used by the Egyptian military spokesman in the military statements on the Comprehensive Operation Sinai 2018. It analyzes the linguistic devices used in each of these strategies. The study also provides a quantitative analysis of each of these strategies. The study, thus, aims at providing a comprehensive model of rhetorical strategies that can be used for the analysis of military statements.

\section{3-Data and Methodology of the Study}

The methodology used is that of Nugus (2009). He proposes a number of rhetorical strategies that can be applied to military statements. The researcher has chosen only the rhetorical strategies relevant to the analyzed data. This methodology has been chosen because it has a functional approach appropriate for the purpose of the investigated data. Other strategies found in the data will be added by the researcher. This is done to reach a comprehensive model of rhetorical strategies that can be used in the analysis of military statements.

The analyzed data consists of 30 military statements issued by the Egyptian military of defense from the beginning of the Comprehensive Operation Sinai in February 2018. The transcripts of the 30 analyzed 
statements have been obtained from the website of the Egyptian Ministry of Defense. The linguistic devices used in each strategy are underlined in the analyzed extracts.

\section{4-Theoretical Background}

Military discourse is defined as a kind of verbal formalization of the typical situation of people's interaction in the military field and a mixture of textual work which are used in such communicative situation (Fakhrutdinova, 2008, p. 261). Thus, it includes written and oral texts used in the context of military communication. It is very precise and is not subject to different interpretations (Hawryluk, 2010, p. 224). Thus, military language is a reflection of the institutional identity of military officials.

There are different classifications of kinds of military discourse. These are: directive, such as instructions, orders and commands; business-organizational directions and guidance; and informative and reference kinds, such as reports ( $\mathrm{Ju}, 2015: 66)$.

Mass media helps in representing the political ideologies of politicians, which is reflected in the language they use. In addition, it helps in shaping public knowledge and ideologies (van Dijk, 1998; Wodak, 2004, 2015). News discourse is socially constructed because the content of news is not only factual information, but also the beliefs and ideologies of the producers. Thus, by analyzing the language of news discourse, the underlying ideologies are clearly indicated as well as the linguistic strategies used to express these ideologies. News discourse makes recipients believe in certain ideologies as it constructs public opinion. Power relations are manifested in media discourse, where recipients are influenced by the ideologies of the more powerful members in a given media discourse (Ali \& Omar, 2016, pp. 131-132).

Military statements are one kind of military discourse. They are officially issued by the armed forces and aim at making the public aware of the latest developments in a given military matter. The same happens in Egypt where the Egyptian armed forces issue military statements to update Egyptians on the latest developments in the Comprehensive Operation Sinai 2018. In military statements, the messages included are shaped in such a way so as to persuade the public of all the achievements.

Nugus (2009) proposes a set of strategies that are used in the Austrian monarchy-republican debate. The researcher proposes that some of these strategies can be used in the analysis of military statements. However, other strategies will be added by the researcher as they are 
relevant to the analyzed data. The strategies of Nugus (2009) that are relevant to the data are:

1-Argument-positioning

2-Formalizing

3-Identifying

4-Objectifying

In the "argument-positioning" strategy, some verbs are used to persuade the audience of the positions adopted by the governmental officials or parties, and convince the public of the truth and correctness of the actions or decisions they take. Examples of these verbs include "resist, advocate, support, defend, oppose, reject, etc." (Nugus, 2009, p. 313).

As for the "formalizing" strategy, texts have formal introductions in which the name of the organization or party that issued the text is indicated, and every action is attributed to the establishment involved (Nugus, 2009, p. 313).

Concerning the "identifying" strategy, the use of pronouns and noun phrases is analyzed to emphasize common identity and solidarity with the audience (Nugus, 2009, pp. 313-314). The second person pronoun "you" and all its forms "your/yours" are also used to express solidarity, common aims, and shared responsibility (Bull \& Fetzer, 2006; Kuo, 2002).

In the "objectifying" strategy, linguistic devices that indicate objectivity are used. These include transition signals, investigative verbs, such as "examined", and deliberative nouns like "evidence", "clues". Numbers are also used to express full objectivity (Nugus, 2009, pp. 320321).

In the data under investigation, the researcher has found that another strategy, which is not indicated by Nugus (2009), is used. This strategy is "assuming power and authority". In fact, assuming power is of great importance in military discourse. van Dijk (in press) clearly states that:

Social power... between social groups...involve the notions of control and access, viz, the control of acts and minds of others in one's own interest...Both control and access in turn involve discourse, first of all in the persuasive processes of mind control, manipulation or the manufacture of consent". There are lexical items that express power and control such as "full control, dominance, power, support, resistance.

These lexical items have positive connotations of power and control. 
Another strategy that is used in the data is "glorification". It is used as a discursive positive self-representation one. In this strategy, lexical items and phrases that have positive connotations are used, such as "the strongest military", "democracy", and "tolerant America" (Unvar \& Rahim, 2013, pp. 13-19). They are used to express the glory and superiority of a person or a nation. There are other linguistic devices that can be used in this strategy, such as comparative and superlative forms. By using these linguistic devices, this strategy emphasizes the concept of positive self-representation and negative-other representation. When someone is manifested positively, then he/she is positively portrayed as more superior than others. This stresses this person's glory. In this way, it is possible to convince the public of the ideas and/or actions indicated.

After the June 30th Revolution in Egypt in 2013, the Egyptian civilian society has been under the attack of terrorist groups and militant organizations, who were supporters of the ousted president Mohamed Morsi and against the people's revolution and all its achievements. The terror attacks were carried out in many Egyptian cities and towns. One of these terrorist attacks was that on El-Rawda mosque in the town of Deir El-Abd in November 2017. This attack killed more than 300 civilians. The Egyptian armed forces were charged by the Egyptian President Abd El-Fattah El-Sisi to begin the counter terror campaign the Comprehensive Operation Sinai 2018. The campaign is against terrorist groups and all criminal organizations hiding in northern and central Sinai as well as some parts of the Nile Delta. The operation started on $9^{\text {th }}$ February, 2018. In this operation, all land, naval, and air forces of the Egyptian armed forces participated in the operation as well as the Egyptian police and border guards.

After launching the Comprehensive Operation Sinai 2018, official military statements have been issued by the Egyptian armed forces. They were filmed and shown on television channels. The aim of these statements is to update Egyptians with the victories and achievements of the Egyptian armed forces in fighting and combating terrorist groups and criminal elements in Sinai and some parts of the Nile Delta.

A number of previous studies have dealt with various issues in military discourse. For example, Petrochenkova (2016) deals with the characteristics of the different genres of the English military discourse. Furthermore, Hawryluk (2010) deals with military linguistics related to the Soviet armed forces. In addition, Okongor (2015) provides an account of the unique characteristics of military language. However, to the researcher's knowledge, there are no studies about Egyptian military 
discourse, especially Egyptian military statements. Thus the present research is an attempt to fill in this gap.

\section{5-Analysis}

This section provides an analysis of the rhetorical strategies and the linguistic devices used in each strategy in the military statements of the comprehensive Operation Sinai 2018

\subsection{Argument-Positioning}

In the data, some argument-positioning verbs, nominal verbs, and/or active and/or passive structures are used to persuade the audience of the positions adopted by the military officials, and convince them of the military achievements in fighting and combating terrorist groups. The verbs are mostly in the passive voice because the achievements are made by all Egyptian officials and soldiers participating in the military operations.

The following extracts illustrate the uses of this strategy in the military statements under investigation:

\section{$\underline{\text { Extract (1) }}$}

...بدأت صباح اليوم قوات انفاذ القانون تنفيذ خطة المجابهة الشاملة...لتطهير المناطق التي يتواجد بها بؤر ارهابية و تحصين المجتمع المصري من شرور الارهاب و التطرف....

...Law enforcement forces have started this morning to carry out the comprehensive confrontation plan...to clear the areas where terror spots are found to protect the Egyptian society from the evils of terror and extremism....

(Statement 1)

\section{$\underline{\operatorname{Extract}(2)}$}

...كما عززت قوات حرس الحدود من إجر اءات التأمين للمناطق الحدودية ...و مجابهة عمليات التسلل

... Border guards also increased the security procedures of border areas... and combating sneaking operations....

(Statement 28)

In the above two extracts, the nominal verbs "تطهير" "clear", " "combating" as well as the verb " and achievements made by the Egyptian armed forces to convince 
Egyptians of the importance of the Comprehensive Operation Sinai 2018 to end terrorism.

\subsection{Formalizing}

All the analyzed military statements have formal introductions where it is clearly stated that these statements are issued by the Egyptian armed forces. Also, in each statement it is stated that these achievements are made by the Egyptian armed forces and the Egyptian police. This is part of the formal structure of the statement. In the statements, each achievement is attributed to the army and/or police division that carried it out. Moreover, each statement has a title that is usually stated at the beginning. The use of this strategy is shown in the following extracts:

\section{Extract (3)}

.... في توقيت متزامن قامت القوات المنفذة مدعومة بالقوات الخاصة بتنفيذ أعمال

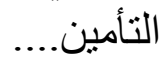

...At the same time, the implementation forces supported by

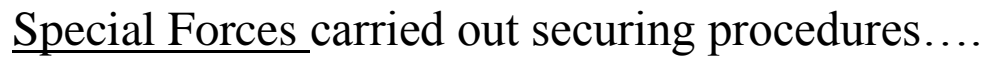

(Statement 3)

\section{$\underline{\operatorname{Extract}(4)}$}

.قيام القو ات الجوية باستهداف و تدمير عدد (9) أهداف خاصة بالعناصر الارهابية...

...The air forces destroyed (9) targets of the terrorist elements....

(Statement 13)

In extracts (3) and (4), it is clearly stated that the army divisions that carried out the actions are the implementation forces supported by Special Forces and air forces. This is done to convince the public of the importance of the military operations carried out in Sinai to fight terrorism, and also to make them aware of the divisions that carried out the successful actions.

\section{$\underline{\text { Extract (5) }}$}

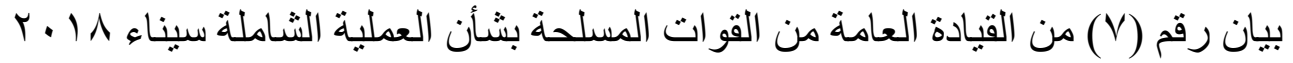

Statement (7) from the General leadership of the Armed forces regarding the Comprehensive Operation Sinai 2018.

(Statement 7)

In the above title of statement (7), it is clearly stated that it is the general leadership of the Egyptian armed forces that issued the statement. 


\subsection{Identifying}

The use of the first and second person pronouns in this strategy manifests that the Egyptian armed forces are part of the Egyptian people, and that the cause they fight for is for the good and benefit of all Egyptians. Military statements usually aim at persuading the audience that they share common goals, and that they are all, armed forces and the people, participants in the glory of the country and work together for the good of their country (Bastow, 2008, p. 142). The first person plural pronoun can be used inclusively, which refers to both the speaker and addressee(s), or exclusively, which refers to the speaker only. Inclusive "we" is used in political discourse by politicians to make people accept any action or decision they take as the only correct one (Beard, 2000, p. 45; Wales, 1996, p. 62). In the analyzed military statements, it is used inclusively to include both the military personnel and the addressees, manifest shared responsibility and show that the operation of fighting terrorism in Sinai is for the good of all Egyptians, not only the armed forces. The use of this strategy is illustrated in the next extracts:

\section{$\underline{\operatorname{Extract}(6)}$}

$$
\text { ....ونتيجة للأعمال القتالية لقو اتتا المسلحة تم استشهاد ضابطين و جنديين.... }
$$

...As a result of the combating acts of our armed forces two officers and two soldiers died as martyrs....

(Statement 14)

The pronoun "our in "our forces" is used inclusively. This use manifests that the officers and soldiers, who died as martyrs, are not only members of the Egyptian armed forces, but are also part of the Egyptian people. Its use here has the advantage of showing that all Egyptians, not only those who serve in the Egyptian army, are participants in defending Egypt.

The use of the second person pronoun in the data is shown in the next extract:

\section{$\underline{\operatorname{Extract}(7)}$}

$$
\text { .... هذا و تو اصل قو اتكم المسلحة واجبها المقدس في الدفاع عن أرض الوطن........ }
$$

...Your armed forces continue its sacred duty in defending the homeland....

(Statement 21)

In the above extract, the second person pronoun "كم" "your" in "Your armed forces" is used to show that the armed forces 
belong to the Egyptians. Thus, they share the common goal of defending Egypt and combating terrorism.

\subsection{Objectifying}

In this strategy, numbers are used to indicate an objective attitude on the part of the Egyptian armed forces. They are also used to indicate the precision of the operation, as illustrated in the next extracts:

\section{$\underline{\operatorname{Extract}(\Lambda)}$}

قيام القوات الجوية... بتدمير عدد (1) هدف بعد تو افر معلومات استخبار اتية مدققة....

...The air forces destroyed (11) targets after the availability of precise intelligence information....

\section{$\underline{\operatorname{Extract}(9)}$}

(Statement 7)

$$
\text { ...تدمير عدد (9) سيار ات أنواع و عدد (10) در اجة نارية.... }
$$

...destroying $\underline{(9)}$ cars of various kinds and $(\underline{15)}$ motor bikes....

(Statement 22)

In the above two extracts, the Egyptian armed forces in the statements clearly indicate the number of the targets and arsenals destroyed to manifest the precision and the success of the operations in Sinai. This shows that the achievements of the armed forces are important as they fully destroy all traces of terror in Sinai Peninsula and all Egyptian land.

\section{$\underline{\text { 5.5. Glorification }}$}

Lexical items and expressions that indicate glorification have positive connotations and positive effects on Egyptians because they clearly show the great respect and admiration the Egyptian armed forces have for its members, who are also Egyptians. In the data, they are used to glorify the army and police members who are participants in the operation in Sinai. Glorifying lexical items and expressions usually attract, and thus persuade, Egyptians of the achievements of the Egyptian armed forces. The use of this strategy is shown in the coming extracts:

\section{$\underline{\text { Extract (10) }}$}

$$
\text { استكمالا للمعارك النبيلة التي يخوضها أبطال القوات المسلحة... }
$$

In continuation of the noble battles fought by heroes of the armed forces and police... 


\section{$\underline{\operatorname{Extract}(11)}$}

$$
\text { استكمالا لمعركة الثرف و الفذاء علي أرض سيناء......... }
$$

In continuation of the battle of honour and sacrifice in Sinai....

(Statement 19)

In the above extracts, the glorifying lexical items "أبطال" "heroes", "honour and sacrifice" are used to show that great achievements have been made by the armed forces. In addition, describing officers and soldiers who participate in these achievements as " "أبطال" "heroes" helps in raising their spirits. Thus, this encourages them to achieve more successes. Also, the description of the battles fought as "honour and sacrifice" helps manifest that this military operation is for the good and safety of Egypt and Egyptians.

\subsection{Assuming Power and Authority}

In the data, there are many lexical items that indicate the power and full control of the Egyptian armed forces of the military operation in Sinai. These lexical items also manifest the great achievements done by the army there. Using this strategy aims at making Egyptians fully trust their armed forces. The use of this strategy is manifested in the following extracts:

\section{$\underline{\operatorname{Extract}(12)}$}

الاستمر ار النجاحات القوات الجوية في فرض سيطرة الدولة علي مختلف الاتجاهات الاستر اتيجية فقد تمكنت من إحباط عملية تهريب أسلحة....

...In continuation of the successes of the air force to impose state control on various strategic directions, they were able to abort arms smuggling...

\section{(Statement 5)}

In the previous extract, there are many lexical items that indicate that the armed forces are in full control of the situation in Sinai, such as "نجاحات "successes" and " "إحباط" "abort".

\section{$\underline{\text { Extract (13) }}$}

...استمرت القوات البحرية في تنفيذ مهامها المخططة وتأمين المسرح البحري من رفح العز و حتي العريش لمنع تسرب العناصر الارهابة عن طريق البحر..... ...The naval forces continued carrying out its carefully planned duties and securing the coast from Rafah until El-Arish to stop the leaking of terrorist elements by sea....

(Statement 9) 
In extract (12), there are also other lexical items that manifest that the armed forces work according to well-planned plans, and that the operations are not carried out randomly. Thus, these operations performed by the armed forces are preceded by careful planning and hard work.

\section{6- Results and Discussion}

The data reveals that only 4 of Nugus' (2009) strategies are used. These are "argument-positioning", "formalizing", "identifying", and "objectifying". However, the researcher has found that two OTHER strategies that are not indicated by Nugus (2009) are used in the data. These are: "glorification" and "assuming power and authority".

Table (1) provides a quantitative analysis of using each rhetorical strategy in the data under investigation:

Table (1) Frequency of using rhetorical Strategies in the data

\begin{tabular}{|l|l|}
\hline Strategy & Frequency of Usage \\
\hline Argument-Positioning & $365(28 \%)$ \\
\hline Objectifying & $347(26.4 \%)$ \\
\hline $\begin{array}{l}\text { Assuming Power and } \\
\text { Authority }\end{array}$ & $280(21.3 \%)$ \\
\hline Formalizing & $142(11 \%)$ \\
\hline Glorification & $120(9.1 \%)$ \\
\hline Identifying & $56(4.2 \%)$ \\
\hline Total & $1310(100 \%)$ \\
\hline
\end{tabular}

Table (1) shows that the total number of strategies used in the data is 1310 . It also shows that the most commonly used rhetorical strategy is "argument-positioning" (365 times, 28\%), followed by "objectifying" (347 times, 26.4\%), "assuming power and authority" (280 times, 21.3\%), "formalizing" (142 times, 11\%), "glorification" (120 times, 9.1\%), and the least used strategy is "identifying" (56 times, 4.2\%).

"Argument-positioning" is the most commonly used strategy because the Egyptian armed forces need to convince Egyptians of the 
purpose of the operation and of their achievements. The next commonly used strategy is "objectifying". This is because numbers portray the precision of the achievements of the army in Sinai, and present to Egyptians the large amount of targets destroyed to make them sure of the success of the military operation. "Assuming power and authority" is the third most commonly used strategy as the armed forces need to assert their power in fighting terrorism. The fourth most commonly used strategy is '"formalizing". This may be because in the official statements the army or police division which achieved a certain success must be clearly indicated. This is done for people to know that all army and police divisions are participating in the military operation in Sinai. This is a way of making Egyptians proud of their army. The following most commonly used strategy is "glorification" where the writer of the statements always makes sure of using glorifying lexical items to describe the army and police members who participate in the military operation, and also to describe the battles fought and the achievements made. This is done to make Egyptians believe in the importance and effectiveness of the operation in Sinai. The least used strategy is "identifying". This is due to the fact that the Egyptian armed forces try to manifest to the people that they share common aims and views with them, and that they know their worries regarding terrorism. In this way, they create solidarity with the public.

\section{Conclusion}

This study has attempted to shed light on the rhetorical strategies used in the military statements issued by the Egyptian army regarding the Comprehensive Operation Sinai 2018. It has also clarified the linguistic techniques used in each strategy as well as the frequency of using each of these strategies.

The study reveals that the most commonly used rhetorical strategy is "argument-positioning" followed by "objectifying", "assuming power and authority", "formalizing", "glorification", and the least used strategy is "identifying". Then, it can be said that these strategies can form a model for the analysis of military statements.

The release of the military statements reflects the fact that the Egyptian armed forces want to show Egyptians the reality of what is going on in Sinai in the Comprehensive Operation Sinai 2018. The Egyptian army seems to create a positive public opinion among Egyptians regarding what is going on in Sinai. They also aim at showing Egyptians that their armed forces have taken revenge for all innocent people killed 
in terrorist operations. In addition, the armed forces manifest that they are capable of defending Egyptian land, and that no threats can affect Egypt at all.

The armed forces also aim at clarifying for Egyptians the extent of terrorist threats facing Egypt. This entails the dire need that they should be prepared at all times to face these threats.

From the previous, the issued military statements are completely objective, and aim at enhancing the trust of Egyptians in their armed forces which pay heavy prices in their fight against terrorism.

Further studies can apply the analyzed strategies on other genres. Also, other rhetorical strategies can be suggested in these genres. The suggested strategies can be a model that can be used to analyze other issues in military discourse. 


\section{$\underline{\text { References }}$}

Ali, M., \& Omar, A. (2016). Discourse and manipulation in the representation of the Russian military intervention in the Syrian Civil War. International Journal of Linguistics, 8(3), 129-140.

Beard, A. (2000). The Language of Politics. London: Routledge.

Bull, P. \& Ftezer, A. (2006). Who are we and who are you? The strategic use of forms of Address in political Interviews. Text \& Talk, 26(1), 3-37.

Fakhrutdinova, D. R. (2008). Structuring of genres of military institutional discourse. Scientific Notes of Kazan University, 150(2), 259266.

Bastow, A. (2008). Defense discourse II: A corpus perspective on routine and rhetoric in defence discourse. In Andrea Mayr (Ed.), Language and Power: An Introduction to Institutional Discourse. London: Continuum International Publishing Group.

Hawryluk, N. (Spring 2010). Military linguistics: Russian in the Red/Soviet army. Journal of Military and Strategic Studies, 12(3),216239.

Petrochenkova, L. (2016). The analysis of communicative strategies and discursive characteristics of different genres of the English military discourse. Russian Linguistic Bulletin, 4(8),80-83.

Ju, D.J (2015). Structural-notional characteristics of multicomponent terms. Moscow: Moscow State Linguistic University, 65-120.

Kuo, S.H. (2002). From solidarity to antagonism: The use of the secondperson singular pronoun in Chinese political discourse. Text, 22(1), 2955 .

Nugus, P. (2009). Rhetorical strategies of political parties and organized movements: Deliberative democracy and the Australian monarchyrepublican debate. Journal of Sociology, 45(3), 307-328.

Okongor, T.A (2015). A Lexico-semantic analysis of military language. International Journal of Humanities and Cultural Studies, 2(3), 652-664. 
Unvar, S. \& Rahim, A. (2013). A critical discourse analysis of discursive strategies in a political text. International Journal of Science and Advanced Technology, 3(3).

van Dijk, T.A. (1998). Opinions and ideologies in the press. In A.G. (Ed.), Approaches to Media Discourse. Oxford: Blackwell.

van Dijk, T.A. (in press). Discourse, power, and control. In , M. Coulthard and C.R. Caldas (Eds), Studies in Critical Discourse Analysis. London: Routledge.

Wales, K. (1996). Personal Pronouns in Present-Day English. Cambridge: CUP.

Wodak, R. (1996). The Disorders of Discourse, Real Language Series. London: Longman.

Wodak, R. (2004). Approaches to media texts. In J.H. Downing (Ed.), The SAGE Handbook of Media Studies (pp.104-123). London: SAGE Publications.

Wodak, R. (2015). The Politics of Fear: What Right-wing Populist Discourse Mean. London: SAGE.

\section{Military Statements Websites}

Statement 1

www.mod.gov.eg/ModWebSite/NewsDetailsAr.aspx/id=32119

Statement 2

www.mod.gov.eg/ModWebSite/NewsDetailsAr.aspx/id=32120

Statement 3

www.mod.gov.eg/ModWebSite/NewsDetailsAr.aspx/id=32121

Statement 4

www.mod.gov.eg/ModWebSite/NewsDetailsAr.aspx/id=32122

Statement 5

www.mod.gov.eg/ModWebSite/NewsDetailsAr.aspx/id=32137 
Statement 6

www.mod.gov.eg/ModWebSite/NewsDetailsAr.aspx/id=32145

Statement 7

www.mod.gov.eg/ModWebSite/NewsDetailsAr.aspx/id=32146

Statement 8

www.mod.gov.eg/ModWebSite/NewsDetailsAr.aspx/id=33160 Statement 9

www.mod.gov.eg/ModWebSite/NewsDetailsAr.aspx/id=33168

Statement 10

www.mod.gov.eg/ModWebSite/NewsDetailsAr.aspx/id=33176

Statement 11

www.mod.gov.eg/ModWebSite/NewsDetailsAr.aspx/id=33186

Statement 12

www.mod.gov.eg/ModWebSite/NewsDetailsAr.aspx/id=33209

Statement 13

www.mod.gov.eg/ModWebSite/NewsDetailsAr.aspx/id=33218

Statement 14

www.mod.gov.eg/ModWebSite/NewsDetailsAr.aspx/id=33230

Statement 15

www.mod.gov.eg/ModWebSite/NewsDetailsAr.aspx/id=33247

Statement 16

www.mod.gov.eg/ModWebSite/NewsDetailsAr.aspx/id=33267

Statement 17

www.mod.gov.eg/ModWebSite/NewsDetailsAr.aspx/id=33290

Statement 18

www.mod.gov.eg/ModWebSite/NewsDetailsAr.aspx/id=343324 
Statement 19

www.mod.gov.eg/ModWebSite/NewsDetailsAr.aspx/id=33332

Statement 20

www.mod.gov.eg/ModWebSite/NewsDetailsAr.aspx/id=33350

Statement 21

www.mod.gov.eg/ModWebSite/NewsDetailsAr.aspx/id=33369

Statement 22

www.mod.gov.eg/ModWebSite/NewsDetailsAr.aspx/id=33376

Statement 23

www.mod.gov.eg/ModWebSite/NewsDetailsAr.aspx/id=33386

Statement 24

www.mod.gov.eg/ModWebSite/NewsDetailsAr.aspx/id=33418

Statement 25

www.mod.gov.eg/ModWebSite/NewsDetailsAr.aspx/id=33438

Statement 26

www.mod.gov.eg/ModWebSite/NewsDetailsAr.aspx/id=33479

Statement 27

www.mod.gov.eg/ModWebSite/NewsDetailsAr.aspx/id=33519

Statement 28

www.mod.gov.eg/ModWebSite/NewsDetailsAr.aspx/id=34588

Statement 29

www.mod.gov.eg/ModWebSite/NewsDetailsAr.aspx/id=34620

Statement 30

http://www.mod.gov.eg/ModWebSite/NewsDetailsAr.aspx?id=35684 